\title{
Pengaruh Kualitas Pelayanan Terhadap Kepuasan Pelanggan Restoran Saung Manglid
}

\author{
Abin Saripudin, ${ }^{1}$ Wawan Oktriawan, ${ }^{2}$ Nunung Kurniasih ${ }^{3}$ \\ STAI DR. KHEZ. Muttaqien Purwakarta
}

abien123@gmail.com

\section{Kata Kunci: \\ Kualitas Pelayanan, \\ Kepuasan Pelanggan, \\ Saung Manglid}

\begin{abstract}
Abstraksi
Penelitian ini bertujuan untuk mengetabui dan menganalisa seberapa besar pengarub kualitas pelayanan terhadap kepuasan pelanggan di Restoran Saung Manglid. Teknik. pengambilan sampel menggunakan Probability Sampling yang berjumlah 96 orang responden. Variabel bebas (X) yang digunakan dalam penelitian ini adalah Bukti Fisik, Keandalan, Daya Tanggap, Jaminan dan Empati dan variabel terikat $(Y)$ dalam penelitian ini adalah Kepuasan Pelanggan. Berdasarkan hasil penelitian diperoleh thitung 12, 465 dan F hitung 155,388 dengan tingkat signifikasi menunjukan sig. 0,000<0,05 yang berarti kualitas pelayanan memiliki pengaruh yang signifikan terbadap kepuasan pelanggan, dan dalam uji $\mathrm{R}$ interpretasi koefisien korelasi didapat sebesar 0,789, terbukti kualitas pelayanan mempunyai bubungan positif dengan kepuasan pelanggan atau tingkat bubungan kuat. Dari hasil analisis data penelitian diketabui bahwa kepuasan pelanggan di Restoran Saung Manglid dipengarubi sebesar 62,3\% oleh kualitas pelayanan, sedangkan 37,7\% dipengarubi oleb variabel lainnya.
\end{abstract}

Copyright (O) 2021 (Abin Syaripudin, dkk.) DOI: https://doi.org/10.52593/mtq.02.1.03 Naskah diterima: 3 November 2020, direvisi: 3 Januari 2021, disetujui: 10 Januari 2021

\section{A. Pendahuluan}

Perkembangan intensitas persaingan dan jumlah pesaing membuat perusahaan harus selalu memperhatikan kebutuhan dan keinginan pelanggan, serta berusaha memenuhi harapan pelanggan dengan cara memberikan pelayanan yang lebih baik daripada yang dilakukan para pesaing ${ }^{1}$. Hal ini dikarenakan pelanggan semakin selektif dalam pemilihan produk untuk digunakan atau dikonsumsi². Konsumen biasanya lebih memilih produk yang berharga murah namun memiliki kualitas yang baik, oleh sebab itu dalam kondisi persaingan yang sangat tinggi, perusahaan harus mampu memahami dan mengetahui keinginan dan kebutuhan agar konsumenya merasa puas. Menurut Kotler dan Keller $^{3}$ kepuasan adalah perasaan senang atau kecewa seseorang yang muncul setelah membandingkan kinerja yang diharapkan. Setelah konsumen mengkonsumsi suatu produk atau jasa, konsumen akan memiliki perasaan puas atau tidak puas terhadap produk atau jasa yang dikonsumsinya. Salah satu faktor yang mempengaruhi kepuasan konsumen adalah kualitas pelayanan.

\footnotetext{
${ }^{1}$ Atmawati, R dan M . Wahyudin, Analisa Pengaruh Kualitas Pelayanan Terhadap Kepuasan Konsumen Pada Matahari Departement Store di Solo ( Surakarta: Jurnal Daya Saing, 2007), 2.

2 Prayuana dan Andjarwati, Pengaruh Penggunaan Celebrity Endorser Irfan Bachdim dan Event Sponsorship Terhadap Citra Merek Minuman Isotonik Pocari Sweat (Jakarta: Jurnal Ilmu Management Vol 1 No 1, 2013), 307-317.

${ }^{3}$ Philip Kotler dan Kevin Lane Keller, Manajemen Pemasaran, Edisi 13 Jilid 1 (Jakarta: Erlangga, 2014), 177.
} 
Menurut Zeithaml, Bitner, dan Gremler ${ }^{4}$ kepuasan konsumen dipengaruhi oleh kualitas pelayanan yang diberikan oleh sebuah perusahaan. Terdapat lima dimensi kualitas pelayanan, yaitu: Tangible, artinya segala bukti fisik seperti pegawai, fasilitas, peralatan, tampilan fisik, dari pelayanan restoran untuk para konsumennya. Reliability, yaitu yang mencakup konsistensi kerja dan kemampuan untuk dipercaya. Hal ini berarti pihak restoran memberikan pelayanannya secara tepat sejak awal dan telah memenuhi permintaan konsumennya. Responsiveness, yaitu kemauan atau kesiapan para karyawan untuk memberikan pelayanannya yang dibutuhkan konsumen. Assurance, meliputi pengetahuan karyawan terhadap produk secara tepat. Para karyawan restoran juga memberikan keramah tamahan perhatian dan kesopanan dalam pelayanannya. Empathy, artinya perhatian secara individual yang diberikan karyawan restoran kepada konsumen seperti kemudahan dalam melakukan pemesanan lewat telepon.

Karakteristik pelayanan dalam pandangan Islam-pun dapat digunakan sebagai panduan, antara lain: Jujur, yaitu sikap yang tidak berbohong, tidak menipu, tidak mengada - adakan fakta, tidak berkhianat serta tidak pernah ingkar,(Effendi, 2020) janji hal ini sesuai dengan firman Allah dalam Al-Quran Surat Asy-Syu'araa' ayat 181-183: "Sempurnakanlah takaran dan janganlah kamu termasuk orang-orang yang merugikan dan timbanglah dengan timbangan yang lurus dan janganlah kamu merugikan manusia pada hak-haknya dan janganlah kamu merajalela dimuka bumi dengan membuat kerusakan"5.

Restoran Saung Manglid merupakan salah satu restoran di Purwakarta, restoran ini dijadikan untuk kajian penelitian, dikarenakan banyaknya pelanggan yang merasa tidak puas dengan pelayanan, harga serta faktor lokasi pun menjadi salah satu kendala bagi para pengunjung dikarenakan area parkirnya kurang memadai. Menurut Bapak Nanang selaku pengelola dan pemilik Restoran Saung Manglid, jumlah pengunjung dari bulan ke bulan berikutnya mengalami fluktuasi. Dari data yang diterima jumlah transaksi pada tahun 2018 jumlah pengunjung sebanyak 1706 pengunjung, tahun 2019 sebanyak 2658 pengunjung dan tahun 2020 sebanyak 230 pengunjung. Jumlah pengunjung yang tidak stabil setiap bulannya yang dialami oleh Restoran Saung Manglid tersebut mungkin dikarenakan rendahnya kualitas pelayanan yang tidak sesuai dengan harapan pelanggan karena kurang maksimal, sehingga perlu dievaluasi kembali.

\section{B. Teori/ Konsep}

Konsep Islam mengajarkan bahwa dalam memberikan layanan dari usaha yang dijalankan, baik itu berupa barang atau jasa, jangan memberikan yang buruk atau tidak berkualitas. Sebagaimana dalam firman Allah SWT pada surat Al-Baqarah ayat 267 sebagai berikut : "Hai orang-orang yang beriman, nafkahkanlah (dijalan Allah) sebagian dari hasil usahamu yang baik-baik dan sebagian dari apa yang kami keluarkan dari bumi untuk kamu dan janganlah kamu memilih yang buruk-buruk lalu kamu nafkahkan darinya padahal kamu

\footnotetext{
${ }^{4}$ Zeithaml, V.A., M.J. Bitner, D.D. Gremler. Services Marketing Edisi 5 (Singapore: McGraw Hill Co.Inc, 2013), 58.

${ }^{5}$ Al-Quran Surat Asy-Syu'araa' Ayat 181-183, Al-Quran Terjemah Indonesia (Jakarta : Sari Agung, 1996), 72 .
} 
sendiri tidak mau mengambilnya melainkan dengan memicingkan mata terhadapnya. Dan ketahuilah bahwa Allah Maha Kaya lagi Maha Terpuji”. ${ }^{6}$

Berdasarkan hal tersebut, penelitian ini mengunakan 2(dua) variabel teori, yaitu pertama, kepuasan pelanggan adalah hal yang paling penting, karena jika pelanggan merasa puas dengan pelayanan atau produk itu, maka posisi produk atau jasa itu akan baik di pasar. Tjiptono ${ }^{7}$ mengungkapkan ada lima indikator penentu kualitas pelayanan yaitu: Bukti Fisik (Tangibles), Keandalan (Reliability), Daya Tanggap (Responsiveness), Jaminan (Assurance) dan Empati (Empathy). Sedangkan yang kedua kepuasan pelanggan ini berkaitan dengan konsumen behavior, indikator yang digunakan untuk mengukur variabel kepuasan diambil menurut Tjiptono ${ }^{8}$ sebagai berikut : Kepuasan pelanggan keseluruhan, Dimensi kepuasan pelanggan, Minat konsumen untuk pembelian ulang, Kesediaan konsumen merekomendasi dan Ketidakpuasan pelanggan

\section{Metode Penelitian/Metode Kajian}

Metode yang dilakukan dalam melakukan penelitian ini adalah kuantitatif deskrptif, dan dilakukan di Restoran Saung Manglid yang beralamat di Jl. Parakanceri, Kecamatan Kiarapedes, Kabupaten Purwakarta, dengan pengumpulan data yang dilakukan melalui penyebaran kuesioner yang dibagikan secara langsung pada responden, yaitu pelanggan di Restoran Saung Manglid. Sedangkan waktu penelitian ini dilakukan pada bulan April 2020.

Terdapat dua variebal dalam penelitian ini, yaitu: pertama, variabel independen / variabel bebas $(\mathrm{X})$, yaitu variabel "kualitas pelayanan", dan kedua variabel dependen / variabel terikat (Y), yaitu variabel "kepuasan pelanggan". Adapun teknik pengumpulan data yang dilakukan dalam penelitian ini adalah dengan : wawancara, pengamatan, angket/kuesioner dan studi kepustakaan dengan jumlah populasi dalam penelitian ini adalah 2,658 orang berdasarkan jumlah konsumen yang berkunjung ke Restoran Saung Manglid pada tahun 2019 dengan sampel 96 orang responden.

$$
n=\frac{2658}{1+2658(0,1)^{2}}=\frac{2658}{27,58}=96,37 \approx 96
$$

\section{Hasil dan Pembahasan}

\section{Hasil Penelitian}

\section{a. Deskripsi Data Tiap Variabel}

Tabel 2. Rekapitulasi Tanggapan Responden Mengenai Kualitas Pelayanan

\begin{tabular}{|c|l|c|c|c|c|}
\hline No & \multicolumn{1}{|c|}{ Sub Variabel } & $\begin{array}{c}\text { Skor } \\
\text { Aktual }\end{array}$ & $\begin{array}{c}\text { Total } \\
\text { Item }\end{array}$ & $\begin{array}{c}\text { Skor } \\
\text { Ideal }\end{array}$ & $\mathbf{\%}$ \\
\hline 1. & Tangibles (Bukti Fisik) & 2425 & 6 & 2880 & $84,20 \%$ \\
\hline 2. & Reliability (Keandalan) & 1205 & 3 & 1440 & $83,68 \%$ \\
\hline 3. & $\begin{array}{l}\text { Responsiveness (Daya } \\
\text { Tanggap) }\end{array}$ & 1202 & 3 & 1440 & $83,47 \%$ \\
\hline 4. & Assurance (Jaminan) & 1616 & 4 & 1920 & $84,16 \%$ \\
\hline
\end{tabular}

\footnotetext{
${ }^{6}$ Al-Quran Surat Al-Baqarah Ayat 267, Al-Quran Terjemah Indonesia (Jakarta : Sari Agung, 1996), 81-82.

${ }^{7}$ Fandy Tjiptono, Strategi Pemasaran (Yogyakarta : Andi, 2015), 77.

${ }^{8}$ Ibid., 368.
} 


\begin{tabular}{|c|c|c|c|c|c|}
\hline 5. & Empathy (Empati) & 1196 & 3 & 1440 & $83,05 \%$ \\
\hline & Total & 7644 & 19 & 9120 & $84 \%$ \\
\hline
\end{tabular}

Sumber: Data diolah 2020

Berdasarkan tabel 2. dapat diketahui bahwa skor tertinggi pada variabel kualitas pelayanan di Restoran Saung Manglid terdapat pada sub variable Tangibles (Bukti Fisik) dimana pada sub variabel ini berada pada indikator yang meliputi fasilitas restoran, perlengkapan dan karyawan yang bersih dan rapi. Sedangkan skor terendah terdapat pada sub variabel Empatby (Empati) dimana pada sub variabel ini berada pada indikator perhatian personal, dan pemahaman kebutuhan secara individual.

Tabel 3. Rekapitulasi Tanggapan Responden Mengenai Kepuasan Pelanggan

\begin{tabular}{|c|l|c|c|c|c|}
\hline No & \multicolumn{1}{|c|}{ Sub Variabel } & $\begin{array}{c}\text { Skor } \\
\text { Aktual }\end{array}$ & $\begin{array}{c}\text { Total } \\
\text { Item }\end{array}$ & $\begin{array}{c}\text { Skor } \\
\text { Ideal }\end{array}$ & $\%$ \\
\hline 1. & $\begin{array}{l}\text { Kepuasan pelanggan secara } \\
\text { keseluruban }\end{array}$ & 1646 & 4 & 1920 & $85,72 \%$ \\
\hline 2. & Dimensi kepuasan pelanggan & 1629 & 4 & 1920 & $84,84 \%$ \\
\hline 3. & Niat beli ulang & 807 & 2 & 960 & $84,06 \%$ \\
\hline 4. & $\begin{array}{l}\text { Kesediaan untuk } \\
\text { merekomendasikan }\end{array}$ & 829 & 2 & 960 & $86,35 \%$ \\
\hline 5. & Ketidakpuasan pelanggan & 2046 & 5 & 2400 & $85,25 \%$ \\
\hline & \multicolumn{1}{|c|}{ Total } & 6957 & 17 & 8160 & $85,25 \%$ \\
\hline
\end{tabular}

Sumber: Data diolah 2020

Berdasarkan tabel 3. dapat diketahui bahwa skor tertinggi pada variabel kepuasan pelanggan di Restoran Saung Manglid adalah terdapat pada sub variabel kesediaan untuk merekomendasikan, sedangkan skor terendah terdapat pada sub variabel yang berada pada niat beli ulang.

\section{b. Uji Kualitas Data}

\section{1). Uji Validitas}

Uji validitas digunakan untuk mengukur sah atau tidaknya suatu kuesioner. Pedoman suatu instrumen dikatakan valid jika $r_{\text {hitung }}$ lebih besar dari $r_{\text {tabel }}$ dan nilai (r) positif. Kriteria yang digunakan dalam menentukan valid tidaknya adalah sebagai berikut:

- Tingkat signifikan sebesar 5\% atau 0,05

- Degree of fredom $(\mathrm{df})=\mathrm{n}-2=96-2=94$, didapat $r_{\text {tabel }}=0,200^{9}$

- Jika $r_{\text {hitung }}>r_{\text {tabel }}$

\section{2). Uji Reliabilitas}

Uji reliabilitas digunakan untuk mengukur konsistensi konstruk atau variabel penelitian. Untuk mengukur uji reliabilitas dilakukan dengan menggunakan uji statistik

${ }^{9}$ Imam Ghozali, Aplikasi Analisis Multivariate Dengan Program IBM SPSS Edisi 7 (Semarang: Undip, 2013), 433. 
Cronbach's Alpha $(\alpha)$. Suatu variabel dikatakan reliabel jika nilai Alpha lebih besar dari $r_{\text {tabel }}$.

Tabel 4. Uji Reliabilitas Kualitas Pelayanan Terhadap Kepuasan Pelanggan

\begin{tabular}{|c|l|c|c|c|}
\hline No. & Item Pertanyaan & Cronbach Alpha & $\boldsymbol{r}_{\text {tabel }}$ & Keterangan \\
\hline 1. & Kualitas Pelayanan $(\mathrm{X})$ & 0,848 & 0,200 & Reliabel \\
\hline 2. & Kepuasan Pelanggan $(\mathrm{Y})$ & 0,854 & 0,200 & Reliabel \\
\hline
\end{tabular}

Sumber: Pengolahan Data SPSS

Berdasarkan hasil uji reliabilitas yang nilai Cronbach Alpa semua variabel lebih besar dari pada $\boldsymbol{r}_{\text {tabel }}$ yaitu Kualitas Pelayanan 0,848 $>0,200$ artinya reliabel, dan untuk Kepuasan Pelanggan 0,854 > 0,200 artinya reliabel dan layak digunakan untuk penelitian.

\section{Analisis dan Pembahasan}

\section{a. Uji Normalitas}

Tabel 5. Uji Normalitas Variabel Kualitas Pelayanan dan Kepuasan Pelanggan

One-Sample Kolmogorov-Smirnov Test

KUALITAS

KEPUASAN

PELAYANAN PELANGGAN

\begin{tabular}{llrr}
\hline N & & 96 & 96 \\
\hline Normal Parameters & Mean & 79,63 & 72,47 \\
\cline { 2 - 4 } Most Extreme Differences & Std. Deviation & 6,947 & 6,214 \\
& Absolute &, 074 &, 070 \\
\cline { 2 - 4 } & Positive &, 040 &, 053 \\
\cline { 2 - 4 } & Negative &,- 074 &,- 070 \\
\hline Test Statistic & &, 074 &, 070 \\
\hline Asymp. Sig. (2-tailed) & &, $200^{\mathrm{c}, \mathrm{d}}$ &, $200^{\mathrm{c}, \mathrm{d}}$ \\
\hline
\end{tabular}

a. Test distribution is Normal.

b. Calculated from data.

c. Lilliefors Significance Correction.

$\mathrm{d}$. This is a lower bound of the true significance.

Berdasarkan hasil perhitungan melalui SPSS versi 25.0 diperoleh bahwa hasil dari Sig sebesar 0,200. Dalam uji normalitas pada kualitas pelayanan dan kepuasan pelanggan yaitu 0,200 > 0,05 yang artinya terima H0 data berdistribusi normal. Dengan demikian dapat disimpulkan bahwa variabel kualitas pelayanan berdistribusi normal.

b. Uji Linieritas

Tabel 6. Rekapitulasi Uji Linieritas

ANOVA Table

\begin{tabular}{|c|c|c|c|c|c|c|c|}
\hline & & & Sum of Squares & $\mathrm{df}$ & $\begin{array}{c}\text { Mean } \\
\text { Square }\end{array}$ & F & Sig. \\
\hline \multirow{5}{*}{$\begin{array}{l}\text { KEPUASAN } \\
\text { PELANGGAN } \\
\text { KUALITAS } \\
\text { PELAYANAN }\end{array}$} & Between & (Combined) & 2722,952 & 26 & 104,729 & 7,647 &, 000 \\
\hline & Groups & Linearity & 2285,388 & 1 & 2285,388 & 166,878 &, 000 \\
\hline & & $\begin{array}{l}\text { Deviation } \\
\text { from Linearity }\end{array}$ & 437,564 & 25 & 17,503 & 1,278 & 211 \\
\hline & Within G & oups & 944,954 & 69 & 13,695 & & \\
\hline & Total & & 3667,906 & 95 & & & \\
\hline
\end{tabular}

Sumber: Hasil Pengolahan Data SPSS 
Berdasarkan nilai signifikasi (Sig.) dari tabel diatas, diperoleh nilai Deviation from Linearity Sig. adalah 0,211 lebih besar dari 0,05. Maka dapat disimpulkan bahwa ada hubungan linear secara signifikan antara variabel Kepuasan Pelanggan (X) dengan variabel Kualitas Pelayanan (Y).

\section{c. Uji Heteroskedastisitas}

\section{Tabel 7. Uji Heteroskedastisitas}

\begin{tabular}{|c|c|c|c|c|c|c|}
\hline \multicolumn{7}{|c|}{ Coefficients $^{a}$} \\
\hline & \multirow[b]{2}{*}{ Model } & \multicolumn{2}{|c|}{$\begin{array}{l}\text { Unstandardized } \\
\text { Coefficients }\end{array}$} & \multirow{2}{*}{$\begin{array}{c}\text { Standardized } \\
\text { Coefficients } \\
\text { Beta } \\
\end{array}$} & & \multirow[b]{2}{*}{ Sig. } \\
\hline & & B & Std. Error & & $\mathrm{t}$ & \\
\hline 1 & (Constant) & 16,250 & 4,527 & & 3,590 &, 001 \\
\hline & KUALITAS & ,706 & ,057 & ,789 & 12,465 &, 000 \\
\hline
\end{tabular}

a. Dependent Variable: KEPUASAN PELANGGAN

Berdasarkan tabel diatas melalui perhitungan SPSS versi 25.0 diketahui nilai signifikasi (sig.) untuk variabel kualitas pelayanan (X) adalah 0,000. Karena nilai signifikasi variabel $\mathrm{X}$ lebih kecil dari 0,05 maka dapat disimpulkan bahwa terjadi gejala heteroskedastisitas.

\section{d. Uji Korelasi Sederhana}

\section{Tabel 8. Uji Korelasi}

Correlations

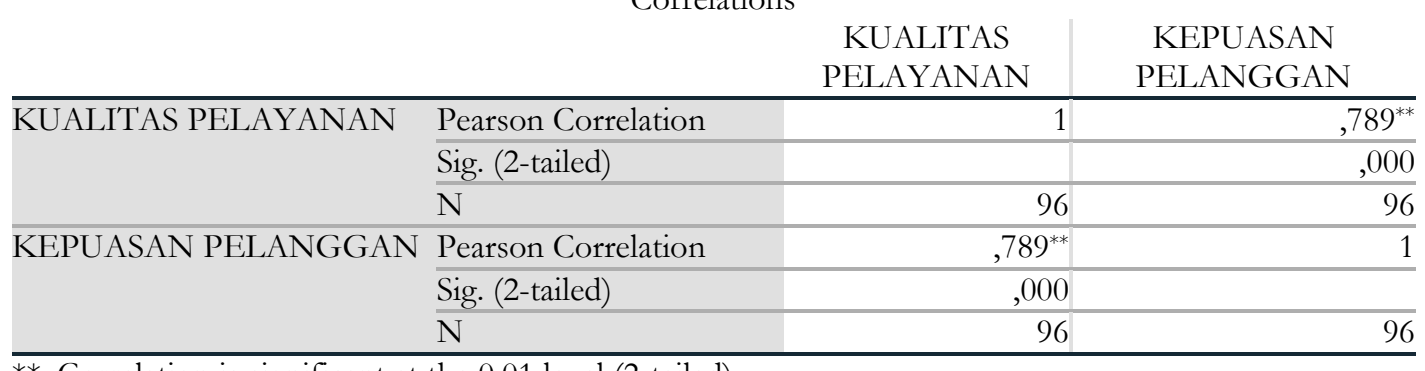

**. Correlation is significant at the 0.01 level (2-tailed).

Pada tabel 8. terlihat nilai korelasi person yang diperoleh sebesar 0,789. Jika dikonfirmasikan dengan tabel interpretasi koefisien korelasi nilai $r$, maka korelasi sebesar 0,789 berada pada tingkat $0,60-0,799^{10}$ yang berarti kualitas pelayanan berpengaruh terhadap kepuasan pelanggan. Karena nilai Sig sebesar 0,000 lebih kecil dari 0,05 $(0,000<0,05)$, artinya signifikan. Terbukti bahwa kualitas pelayanan mempunyai hubungan positif dan signifikan dengan kepuasan pelanggan atau tingkat hubungan: Kuat ${ }^{11}$.

\section{e. Uji Regresi Linier Sederhana}

\section{Tabel 9. Uji Regresi}

Coefficients $^{\mathrm{a}}$

\footnotetext{
${ }^{10}$ Sugiyono, Metode Penelitian Kuantitatif, Kualitatif dan NRD (Bandung: Alfabeta, 2016), 278.

11 Ibid.
} 


\begin{tabular}{|c|c|c|c|c|c|c|}
\hline \multirow{2}{*}{\multicolumn{2}{|c|}{ Model }} & \multicolumn{2}{|c|}{ Unstandardized Coefficients } & \multirow{2}{*}{$\begin{array}{c}\text { Standardized } \\
\text { Coefficients } \\
\text { Beta }\end{array}$} & \multirow[b]{2}{*}{$\mathrm{t}$} & \multirow[b]{2}{*}{ Sig. } \\
\hline & & $\mathrm{B}$ & Std. Error & & & \\
\hline 1 & (Constant) & 16,250 & 4,527 & & 3,590 & ,001 \\
\hline & $\begin{array}{l}\text { KUALITAS } \\
\text { PELAYANAN }\end{array}$ & ,706 & 057 & ,789 & 12,465 & ,000 \\
\hline
\end{tabular}

a. Dependent Variable: KEPUASAN PELANGGAN

Pada tabel di atas, menunjukkan $\mathrm{a}=$ angka konstan dari unstandardized coefficients yang nilainya sebesar 16,250 sedangkan $\mathrm{b}=$ angka koefisien regresi yang nilainya sebesar 0,706, sehingga persamaan regresinya adalah:

$$
\begin{aligned}
& \breve{Y}=a+b X \\
& \breve{Y}=16,250+0,706 X
\end{aligned}
$$

Dengan demikian dapat dikatakan bahwa Kualitas Pelayanan berpengaruh positif terhadap Kepuasan Pelanggan. Diperoleh $t_{\text {hitung }}=12,465$ dan tingkat signifikan 0.000. Prosedur mencari statistik tabel dengan kriteria tingkat signifikansi $(\alpha=0,05)$ untuk uji dua pihak serta df atau dk (derajat kebebasan) $=\mathrm{n}-2$ atau $96-2=94$. Sehingga didapat $t_{\text {tabel }}=$ 1,985. Dengan demikian $t_{\text {hitung }}>t_{\text {tabel }}$ atau $12,465>1,985$ dan nilai probabilitas 0,05 lebih besar dari nilai Sig $(0,05>0,000)$, Jadi, kualitas pelayanan berpengaruh signifikan terhadap kepuasan pelanggan di Restoran Saung Manglid.

\section{f. Uji Koefisien Determinasi}

\begin{tabular}{|c|c|c|c|c|}
\hline \multicolumn{5}{|c|}{ Model Summary } \\
\hline Model & $\mathrm{R}$ & R Square & Adjusted R Square & Std. Error of the Estimate \\
\hline$\overline{1}$ & ,789a & ,623 & ,619 & 3,835 \\
\hline
\end{tabular}

\section{Tabel 10. Koefisien Determinasi}

Tabel Model Summary diatas menunjukan bahwa nilai $\mathrm{R}$ adalah 0,789 dan koefisien determinasi ( $\mathrm{R}$ Square sebesar 0,623 adalah pengkuadratan dari koefisien korelasi atau 0,789 x 0,789 = 0,623). Artinya kepuasan pelanggan $(Y)$ dipengaruhi sebesar $62,3 \%$ oleh kualitas pelayanan (X). Sedangkan 37,7\% lainnya dijelaskan oleh variabel lain. Jika dikonfirmasi dengan tabel interpretasi koefisien korelasi nilai r, nilai R Square ini berada pada 0,60 - 0,799 tingkat hubungan: $\mathrm{Kuat}^{12}$.

\section{g. Uji Signifikasi}

1). Uji t

\section{Tabel 11. Uji Hipotesis Penelitian}

\begin{tabular}{l|c|c|c}
\multicolumn{2}{c}{ Coefficients $^{\mathrm{a}}$} & \\
Model & $\begin{array}{c}\text { Standardized } \\
\text { Coefficients }\end{array}$ & t & Sig.
\end{tabular}

\footnotetext{
12 Ibid.
} 


\begin{tabular}{|c|c|c|c|c|c|c|}
\hline \multirow[b]{2}{*}{1} & & B & Std. Error & Beta & & \\
\hline & (Constant) & 16,250 & 4,527 & & 3,590 & $\overline{, 001}$ \\
\hline & $\begin{array}{l}\text { KUALITAS } \\
\text { PELAYANAN }\end{array}$ &, 706 & 057 & ,789 & 12,465 &, 000 \\
\hline
\end{tabular}

a. Dependent Variable: KEPUASAN PELANGGAN

Pada tabel analisis, diperoleh $\mathrm{t}$ hitung $=12,465$ dan tingkat signifikan 0.000. dengan tingkat signifikansi $(\alpha=0,05)$ untuk uji dua pihak serta $\mathrm{df}$ atau $\mathrm{dk}$ (derajat kebebasan) $=\mathrm{n}-2$ atau $96-2=94$. Sehingga didapat $\mathrm{t}$ tabel $=1$,985. Dengan demikian, $t_{\text {hitung }} \geq t_{\text {tabel }}$ atau $(12,465>1,985)$ atau nilai probabilitas 0,05 lebih besar dari nilai Sig $(0,05>0,000)$, dengan demikian $\mathrm{H}_{\mathrm{o}}$ ditolak dan $\mathrm{H}_{\mathrm{a}}$ diterima, artinya signifikan. Jadi, kualitas pelayanan berpengaruh secara signifikan terhadap kepuasan pelanggan di Restoran Saung Manglid.

2). Uji F

Tabel 12. Uji Hipotesis Penelitian

ANOVAa

\begin{tabular}{llr|r|r|r|r} 
& Model & Sum of Squares & df & Mean Square & \multicolumn{1}{c}{ F } & \multicolumn{1}{c}{ Sig. } \\
\hline 1 & 2285,388 & 1 & 2285,388 & 155,388 &, $000^{\mathrm{b}}$ \\
\cline { 2 - 6 } & Regression & 1382,519 & 94 & 14,708 & & \\
\hline Residual & 3667,906 & 95 & & & \\
\hline Total & & & &
\end{tabular}

a. Dependent Variable: TOTALY

b. Predictors: (Constant), TOTALX

Berdasarkan tabel Anova diatas diketahui nilai F hitung adalah sebesar 155,388 dengan kriterian signifikasi 0,05 , dan diketahuin nilai $\mathrm{F}$ tabel sebesar 3,94. Karena nilai $\mathrm{F}$ hitung 155,388 > 3,94, maka dapat disimpulkan bahwa hipotesis diterima. Diperoleh nilai signifikasi (Sig.) $=0,000$, maka diperoleh hasil $0,000<0,05$, yang artinya kualitas pelayanan (X) berpengaruh terhadap kepuasan pelanggan $(\mathrm{Y})$

\section{E. Simpulan}

Berdasarkan hasil penelitian yang telah dilakukan, secara keseluruhan hasil penelitian ini menunjukan adanya pengaruh antara kualitas pelayanan terhadap kepuasan pelanggan di Restoran Saung Manglid. Hasil dari uji signifikan dengan menggunakan analisis korelasi pada nilai propabilitas $0,05 \geq 0,000$, maka $H_{o}$ ditolak dan $H_{a}$ diterima, artinya signifikan. Jadi terbukti bahwa kualitas pelayanan mempunyai pengaruh secara signifikan dengan kepuasan pelanggan di Restoran Saung Manglid. Hasil dari analisis regresi uji t diperoleh $t_{\text {hitung }}=$ 12,465 dan tingkat signifikan 0,000 , maka $t_{\text {hitung }}>t_{\text {tabel }}$ atau 12,465 $>1,985$ dan nilai probabilitas $0,05 \geq 0,000$, dengan demikian maka $H_{0}$ ditolak dan $H_{a}$ diterima artinya signifikan. Sementara berdasarkan uji F diperoleh $F_{\text {hitung }}=155,388$ dan tingkat signifikan 0,000, maka 155,388 > 3,94 dan nilai probabilitas $0,05 \geq 0,000$, maka hipotesis diterima, dengan demikian kualitas pelayanan berpengaruh signifikan terhadap kepuasan pelanggan Restoran Saung Manglid.

Berdasarkan koefisien determinan (R Square) sebesar 0,623 terlihat bahwa pengaruh kualitas pelayanan $(\mathrm{X})$ terhadap kepuasan pelanggan $(\mathrm{Y})$, dinilai positif sebesar $62,3 \%$ sedangkan 37,7\% lainnya dijelaskan oleh variabel lain. Jika dikonfirmasi dengan tabel 
interpretasi koefisien korelasi nilai $r$, nilai $\mathrm{R}$ Square ini berada pada 0,60 - 0,799 dengan tingkat hubungan : Kuat. Diperoleh pula nilai konstanta 16,250 dan beta 0,706 dengan demikian persamaan regresi $\mathrm{Y}=\mathrm{a}+\mathrm{bX}$ atau 16,250 + 0,706X. Ini berarti bahwa variabel $\mathrm{X}$ (kualitas pelayanan) berpengaruh terhadap Y (kepuasan pelanggan) dengan diikuti penilaian sebesar 0,706. Dengan kata lain variabel $\mathrm{X}$ mempunyai pengaruh dengan variabel $\mathrm{Y}$ dengan arah perubahan positif. Hal ini berarti bahwa kualitas pelayanan berpengaruh positif terhadap kepuasan pelanggan.

Bila kualitas pelayanan sesuai dengan harapan, pelanggan akan puas, dan apabila pelayanan melebihi harapan, pelanggan akan sangat puas. Sehingga apabila konsumen sudah merasa semua kenyataan sesuai dengan harapan maka konsumen akan merasa puas. Berdasarkan hasil penelitian, pembahasan dan kesimpulan yang telah diperoleh, ada beberapa rekomendasi untuk meningkatkan kepuasan pelanggan pada Restoran Saung Manglid diantaranya:

1) Kepada Restoran Saung Manglid diharapkan dapat terus meningkatkan dan mempertahankan kualitas produk, fasilitas dan pelayanan karena terbukti mampu menjadi patokan bagi konsumen untuk tetap menjadi pelanggan yang setia.

2) Harus mempunyai konsep untuk menarik para konsumen agar bisa datang kembali (niat beli ulang) dengan memperhatikan lokasi tempat usaha harus strategis, nyaman dan harga yang kompetitif serta memberikan inovasi pada variasi menunya sehingga banyak konsumen yang berdatangan kembali, mengingat pembeli adalah raja sehingga harus ramah pada setiap konsumen atau pembeli yang berdatangan sehingga akan tercipta kepuasan tersendiri bagi konsumen.

\section{Daftar Pustaka}

A. Parasuraman, Valarie A. Zeithaml, and Leonard L. Berry. 1988. 'SERVQUAL A MultipleItem Scale For Measuring Consumer Perceptions of Service Quality'. Jurnal of Retailing, Vol 67 No. 4.

Agama, Departemen (TNI Angkatan Darat cetakan ke X). 1996. Alquran Terjemah Indonesia. Jakarta: PT. Sari Agung.

Arikunto, Suharsimi. 2000. Manajemen Penelitian. Jakarta: Rineka Cipta.

Atmawati, R dan M. Wahyudin. 2007. Analisa Pengarub Kualitas Pelayanan Terbadap Kepuasan Konsumen Pada Matahari Departemen Store di Solo. Surakarta: Jurnal Daya Saing.

Effendi, M. R. (2020). Mitigasi Intoleransi dan Radikalisme Beragama di Pondok Pesantren

Melalui Pendekatan Pembelajaran Inklusif. Paedagogie, I(I), 55-74.

https://doi.org/doi.org/10.20211/pdg.01.1.05

Effendi, M. R. (2020). Mitigasi Intoleransi dan Radikalisme Beragama di Pondok Pesantren

Melalui Pendekatan Pembelajaran Inklusif. Paedagogie | Jurnal Pendidikan dan Studi Islam, 1(1), $56-75$. 
Ghozali, Imam. 2013. Aplikasi Analisis Multivariete Dengan Program SPSS Edisi ke 7. Semarang: Undip.

Kotler, Philip. 2002. Manajemen Pemasaran, Edisi 13 Jilid 2. Jakarta: Erlangga

Prayuana dan Andjarwati. 2013. Pengaruh Penggunaan Celebrity Endorser Irfan Bachdim dan Event Sponsorship Terbadap Citra Merek Minuman Isotonik Pocari Sweat. Jakarta: Jurnal Ilmu Manajemen Vol 1 No 1.

Riduwan dan Sunarto. 2014. Pengantar Statistika: Untuk Penelitian, Pendidikan, Sosial, Ekonomi, Komunikasi dan Bisnis. Bandung: Alfabeta.

Riduwan. 2016. Dasar-Dasar Statistika. Bandung: Alfabeta.

—. 2013. Rumus dan Data Dalam Analisis Statistika. Bandung: Alfabeta.

Sugiyono. 2017. Metode Penelitian Bisnis. Bandung: Alfabeta.

—. 2016. Metode Penelitian Kuantitatif, Kualikatif dan RND. Bandung: Alfabeta.

Tjiptono, Fandy. 2015. Pemasaran Jasa. Yogyakarta: Andi.

Umar, Husein. 2014. Metode Penelitian Untuk Skripsi san Tesis Bisnis Edisi ke 2. Jakarta: Rajawali Pers.

Zeithaml, V.A., M.J. Bitner, D.D. Gremler. 2013. Services Marketing. Singapore :McGraw Hill Co. Inc.

\section{Website :}

Tips Serba Serbi (2020). Kualitas Pelayanan Menurut Perspektif Islam. https://tipsserbaserbi.blogspot.com/2015/03/kualitas-pelayanan-menurutperspektif.html?m=1. Diunduh pada tanggal 27 Juni 2020. 